\title{
EFFECT OF REHYDRATION OF UNHYDRATED CEMENT ON ULTRA-HIGH PERFORMANCE CONCRETE AFTER HEAT CURING
}

\author{
XIONG WU*, **, ${ }^{*}$ YAOLING LUO**, WEN YANG**, YUXIN GAO**, YAO BI**, YUHAO XIE** \\ *School of Materials Science and Engineering, Wuhan University of Technology, Wuhan 430070, China \\ **China West Construction Academy of Building Materials, Chengdu, 610015, China \\ "E-mail: cqulyl@qq.com
}

Submitted April 28, 2021; accepted August 16, 2021

\begin{abstract}
Keywords: UHPC, Unhydrated cement, Moisture susceptibility, Pore structure
Mechanical performance testing, X-ray diffraction (XRD), scanning electron microscopy (SEM) and mercury intrusion porosimetry (MIP) were used to study the effect of rehydration of unhydrated cement on ultra-high performance concrete (UHPC) under contact moisture and to isolate the moisture environments after different curing temperatures. The results indicated that the unhydrated cement particles can continuously hydrate when in contact with moisture and reduce the porosity, especially the $10 \sim 100 \mathrm{~nm}$ pores, and continuously improve the late strength of UHPC at $20^{\circ} \mathrm{C}$ and $90{ }^{\circ} \mathrm{C}$ under a contact moisture environment. Contact with moisture will significantly increase the porosity and the $10 \sim 100 \mathrm{~nm}$ pores of the specimen, thereby leading to severe strength shrinkage and causing moisture susceptibility problems to the UHPC, while the isolated moisture also causes a slight reduction in the strength after curing at $250{ }^{\circ} \mathrm{C}$. Contact with moisture can cause more severe strength shrinkage when the curing temperature is $250^{\circ} \mathrm{C}$.
\end{abstract}

\section{INTRODUCTION}

Ultra-high performance concrete (UHPC) has ultrahigh strength, ultra-high toughness and ultra-high durability. Its compressive strength and flexural strength are usually larger than $150 \mathrm{MPa}$ and $20 \mathrm{MPa}$, respectively. The water-binder ratio of UHPC is usually lower than 0.20 and could reach $0.13[1-3]$. The cement will not fully hydrate when the water-binder ratio is below 0.42 [4]. UHPC with a very low water-binder ratio and a large amount of cementitious material leads to unhydrated cement particles, whose content may account for more than $50 \%$ [5]. The results of Vandamme [6] indicated that the content of unhydrated cement particles was $41 \%$ in a 0.15 water-binder ratio cement paste and $30 \%$ in a 0.20 water-binder ratio cement paste. External moisture enters the concrete structure, which leads to the hydration of unhydrated cement particles and causes expansion and cracking in wet or water environments. The process provides passage for harmful substances from the outside to enter the concrete, accelerates the deterioration of the concrete, affects the long-term performance of the concrete, and shortens the service life of the concrete, thus indicating the moisture susceptibility of the cement. This phenomenon was identified by B. Hillemeier and M. Schroder. Concrete with a water-cement ratio of 0.30 and a compressive strength of $130 \mathrm{MPa}$ for 28 days was tested for accelerated hydration in $90{ }^{\circ} \mathrm{C}$ water, where a large number of visible cracks was observed after 7 days [7]. Powers showed that the volume of the solid increased to $210 \%$ when the unhydrated cement particles interact with the external water to form hydration products [4]. According to the hydration degree, the content of the unhydrated cement particles and the quantitative relationship between the porosity and water-binder ratio, the hydration products of the late hydration of concrete will not have enough pore volume for growth when the water-binder ratio is lower than 0.36 . As a result, the growth of new hydration products may lead to an increase in the internal pressure, resulting in microcracks that provide a channel for external moisture to enter the cement-based material, thus providing more moisture for hydration. Finally, cracks in the structure develop and become linked, which affects the durability and service life of the concrete. This phenomenon is more serious in low water-binder ratio cement-based materials. G.K.D. Pushpalal and T. Kobayashi showed that the late hydration of unhydrated particles has a negative effect on the linear expansion rate, elastic modulus and mass change rate of cement-based materials [8].

The long-term reduction in the concrete's strength refers to situations in which the strength at a late age $(90 \mathrm{~d})$ is lower than the initial strength $(7 \mathrm{~d}, 28 \mathrm{~d})$ under normal mixing ratios and curing conditions. Scholars 
have found that the strength reduction also occurs in UHPC, especially after heat curing. The strength of the UHPC is often enhanced by heat curing [9-17]. The microstructure behaviour of reactive powder concrete (RPC) under different heating regimes was studied by Chi-ming Tam [16], and the results indicated that there were no special crystal structures under a $100{ }^{\circ} \mathrm{C}$ heating regime. Tobermorite was found under a $150{ }^{\circ} \mathrm{C}$ heating regime, a small amount of xonotlite was found under a $200{ }^{\circ} \mathrm{C}$ heating regime, and a large amount of xonotlite was found under a $250{ }^{\circ} \mathrm{C}$ heating regime. Many researchers have shown that UHPC presents a long-term strength reduction to different degrees under thermal curing or high temperatures [19-21]. In a study on the influence of curing conditions on the strength of RPC, He Feng et al [22] found that the strength of the RPC would shrink when it was put in water or indoors after thermal curing and the degree of reduction was greater when it was placed in water after high temperature curing than when it was placed indoors. Wu Yanhai et al [23] found that the strength shrinkage of RPC under $200{ }^{\circ} \mathrm{C}$ dry heat curing was more obvious than that of steam curing at the same temperature for 28 days. The control of the curing temperature and time within a certain range will promote the hydration of UHPC and contribute to the improvement of its mechanical properties, but beyond a certain range, it will cause a certain degree of damage to the internal microstructure of the UHPC and affect the thermal curing effect. In addition, the authors found that the UHPC had a compressive strength reduction after high-temperature heating, especially at curing temperatures over $200{ }^{\circ} \mathrm{C}$.

The damage to the structure from the concrete strength reduction is obvious; therefore, the mechanism underlying the long-term strength reduction of UHPC must be further analysed to explore the solution to the problem to reduce the damage caused by the long-term strength reduction of concrete. In addition, specific research has not been performed on the reasons for the compressive strength reduction of UHPC in the later stage of thermal curing, especially whether it is related to the moisture susceptibility in the later stage. Therefore, this paper studied the long-term performance changes of UHPC under normal temperature curing and two different heat curing methods $\left(90{ }^{\circ} \mathrm{C}\right.$ steam curing and $250{ }^{\circ} \mathrm{C}$ dry heat curing) in isolation water and contact water environments to explore the influence and mechanism of water on the moisture susceptibility of UHPC in the later stage of thermal curing.

\section{EXPERIMENTAL}

Preparation of the basic materials

Ordinary Portland cement 52.5R, semi-encrypted grade 94 silica fume and S95 granulated blast furnace slag were used in this paper. The main chemical compositions of the three powders are shown in Table 1, and the XRD patterns of the three powders are shown in Figure 1.

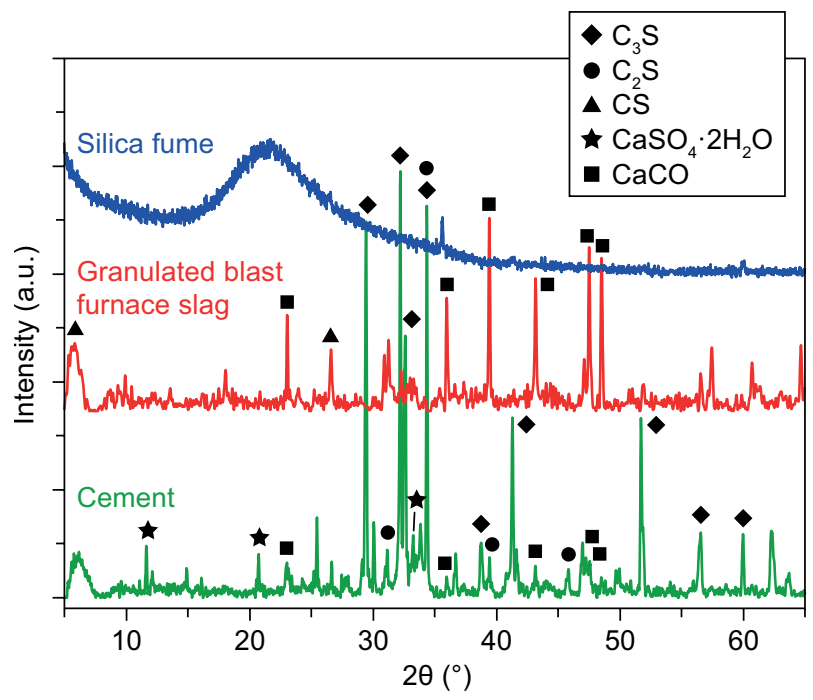

Figure 1. XRD of the cementitious materials.

Fine aggregate: Natural river sand was used after screening and grading, and the fineness modulus of the natural river sand was 1.8 .

Chemical admixture: An admixture for UHPC with high water reduction, viscosity reduction and shrinkage reduction functions was adopted.

\section{Design of the experiments}

According to the mix proportion of the UHPC shown in Table 2, different curing temperature tests were performed to mould the $40 \times 40 \times 160 \mathrm{~mm}$ samples.

Table 2. Mix proportions of the UHPC.

\begin{tabular}{cccccc}
\hline Cement & $\begin{array}{c}\text { Gran. blast } \\
\text { furnace slag }\end{array}$ & $\begin{array}{c}\text { Silica } \\
\text { fume }\end{array}$ & Sand & Water & Admixture \\
\hline 1.0 & 0.30 & 0.23 & 1.53 & 0.24 & 0.01 \\
\hline
\end{tabular}

Table 1. Chemical compositions of the raw materials (wt. \%).

\begin{tabular}{lcrrrrrrrrrcc}
\hline Materials & $\mathrm{SiO}_{2}$ & $\mathrm{Al}_{2} \mathrm{O}_{3}$ & $\mathrm{CaO}$ & $\mathrm{MgO}$ & $\mathrm{Na}_{2} \mathrm{O}$ & $\mathrm{K}_{2} \mathrm{O}$ & $\mathrm{Fe}_{2} \mathrm{O}_{3}$ & $\mathrm{TiO}_{2}$ & $\mathrm{SO}_{3}$ & $\mathrm{P}_{2} \mathrm{O}_{5}$ & $\mathrm{MnO}$ & $\mathrm{SrO}$ \\
\hline Cement & 21.39 & 5.15 & 61.04 & 2.82 & 0.638 & 0.615 & 3.86 & 0.848 & 3.1 & 0.095 & - & - \\
Gran. blast furnace slag & 11.70 & 11.15 & 57.23 & 11.74 & 0.682 & 0.536 & 2.62 & 2.180 & 1.6 & - & 0.438 & 0.126 \\
Silica fume & 95.61 & - & 1.81 & 1.91 & 0.665 & - & - & - & - & - & - & - \\
\hline
\end{tabular}


Curing system: Standard curing, $90{ }^{\circ} \mathrm{C}$ steam curing and $250{ }^{\circ} \mathrm{C}$ heat curing were used in this paper. The samples were subjected to standard curing for 3 days after demoulding, after which the samples were placed in different heat curing environments for 7 days (shown in Figure 2). The samples were placed in a contact moisture environment, and the moisture environment was isolated at every test age. The groups and grouping interpretation are shown in Table 3.

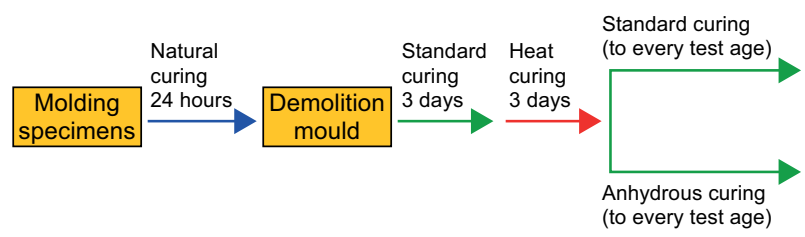

Figure 2. Curing methods.

Test age: The mechanical properties and microstructure of the samples were tested at 7, 28, 60, 90 and 180 days. Contact moisture: The samples were placed in an environment with a relative humidity of $95 \%$ after curing, and the curing temperature was $25^{\circ} \mathrm{C}$.

Moisture isolation: The samples were completely covered with plastic wrap to keep out moisture after curing, and the curing temperature was $25^{\circ} \mathrm{C}$.

$90^{\circ} \mathrm{C}$ steam curing: The curing temperature was $90{ }^{\circ} \mathrm{C}$, and the relative humidity was $98 \%$.

Heat curing at $250{ }^{\circ} \mathrm{C}$ : The curing temperature was $250{ }^{\circ} \mathrm{C}$, and the relative humidity was $0 \%$.

\section{Test methods}

Mechanical performance testing: The flexural strength and compressive strength of the UHPC were tested at various ages per the Chinese standard GB/T 176711999. The specimen size was $40 \times 40 \times 160 \mathrm{~mm}$.

Scanning electron microscopy (SEM): The samples were dehydrated by absolute ethyl alcohol for $48 \mathrm{~h}$, and then the samples were tested after vacuum drying at $60{ }^{\circ} \mathrm{C}$. SEM/energy dispersive X-ray spectroscopy (EDS) was performed using a Tescan VEGA III LMU scanning electron microscope. The main parameters were a high vacuum resolution of $3.0 \mathrm{~nm} / 30 \mathrm{kV}$ and a low vacuum resolution of $3.5 \mathrm{~nm} / 30 \mathrm{kV}$. The magnification was $4 \sim 100000$ times, the operating voltage was $0.2 \sim 30 \mathrm{kV}$, the electron beam current was $1 \mathrm{pA} \sim 2 \mathrm{a}$, and the changes in the microstructure of the materials in the sample after erosion were directly observed by SEM.

$X$-ray diffraction $(X R D)$ : The samples were dehydrated by absolute ethyl alcohol for $48 \mathrm{~h}$, and then the samples were tested after vacuum drying at $60{ }^{\circ} \mathrm{C}$. Then, the samples were ground in a ceramic mortar to pass through an $80 \mu \mathrm{m}$ square-hole sieve. A PANalytical Empyrean X-ray diffractometer was used to analyse the phase composition. The target material of the instrument was copper, the scanning range was $5 \sim 70^{\circ}$, and the scanning speed was 5 minutes for a sample.

Mercury intrusion porosimetry (MIP): The samples were dehydrated by absolute ethyl alcohol for $48 \mathrm{~h}$, and then the samples were tested after vacuum drying at $60{ }^{\circ} \mathrm{C}$. The block samples should be less than $1.5 \times 1.5 \times 1.5 \mathrm{~cm}$. An Auto Pore IV 9510 from McMaretic Instruments Inc. was used to determine the porosimetry. For the low pressure station, the pressure range was $0.2-50 \mathrm{psi}$ $(1.38-310 \mathrm{kPa})$; for the high pressure station, the maximum pressure reached 60000 psi. The aperture analysis range was $0.003 \mu \mathrm{m}$ to $1000 \mu \mathrm{m}$.

\section{RESULTS AND DISCUSSION}

\section{Mechanical properties}

The mechanical properties of the samples were tested at 7, 28, 60, 90, 180 days and are shown in Figure 3 to Figure 5. The mechanical properties of the samples under the $20{ }^{\circ} \mathrm{C}$ standard curing are shown in Figure 3. There was no discernible effect on the compressive strength of the samples under the contact moisture and isolated moisture environments. The early stage compressive strength and flexural strength can be enhanced by the contact moisture.

The mechanical properties of the samples under $90{ }^{\circ} \mathrm{C}$ steam curing are shown in Figure 4. The compres-

Table 3. Curing methods and test groups.

\begin{tabular}{lll}
\hline Groups & Grouping interpretation \\
\hline Control group & Contact moisture & 1 day demoulding + contact moisture curing to every test age \\
\cline { 2 - 3 } 90 & Isolate moisture & 1 day demoulding + isolate moisture curing to every test age \\
\hline \multirow{3}{*}{$250{ }^{\circ} \mathrm{C}$ steam curing heat curing } & Contact moisture & $\begin{array}{l}1 \text { day demoulding }+3 \text { days standard curing }+3 \text { days } 90{ }^{\circ} \mathrm{C} \text { steam curing }+ \text { contact } \\
\text { moisture curing to every test age }\end{array}$ \\
\cline { 2 - 3 } & Isolate moisture & $\begin{array}{l}1 \text { day demoulding }+3 \text { days standard curing }+3 \text { days } 90{ }^{\circ} \mathrm{C} \text { steam curing }+ \text { isolate } \\
\text { moisture curing to every test age }\end{array}$ \\
\cline { 2 - 3 } & Contact moisture & $\begin{array}{l}1 \text { day demoulding }+3 \text { days standard curing }+3 \text { days } 250{ }^{\circ} \mathrm{C} \text { heat curing }+ \text { contact } \\
\text { moisture curing to every test age }\end{array}$ \\
\hline
\end{tabular}


sive strength of the samples was slightly lower in the contact moisture environment at 28 days while higher at the long-term age. The flexural strength can be enhanced by the contact moisture.

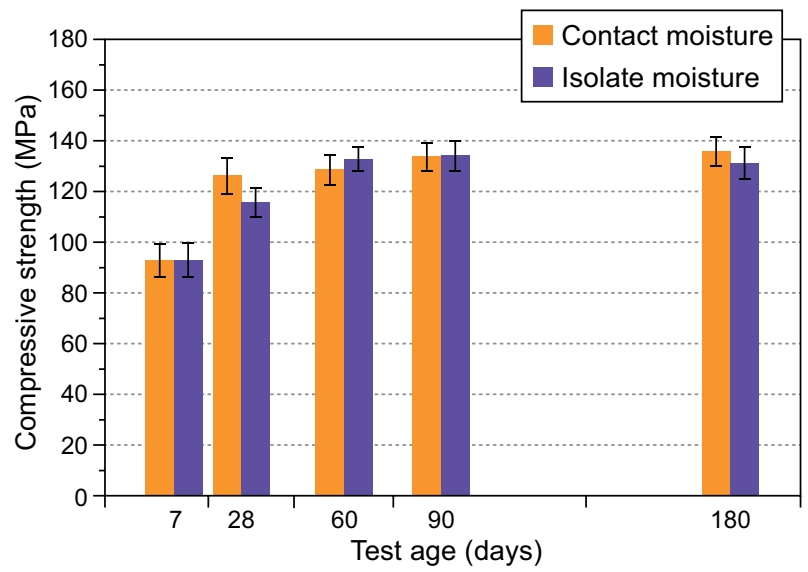

a) Compressive strength

Figure 3. Strength of the $20^{\circ} \mathrm{C}$ standard curing.

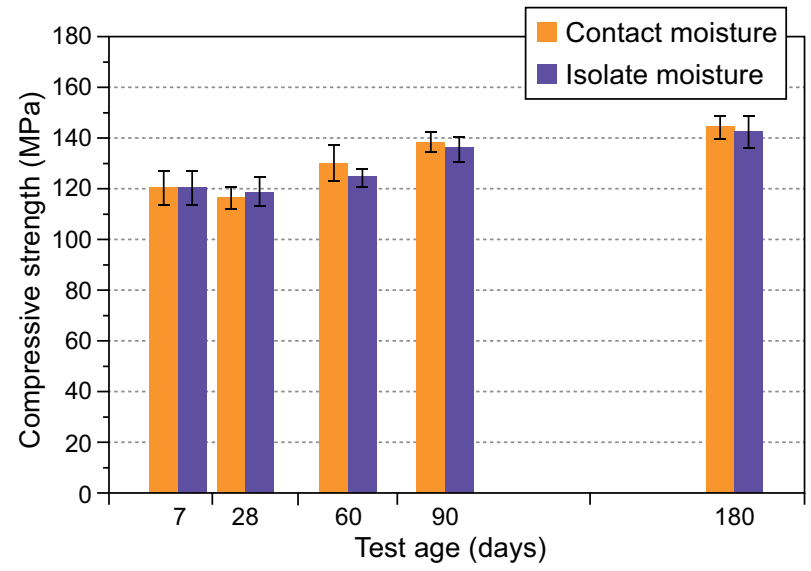

a) Compressive strength

Figure 4. Strength of the $90{ }^{\circ} \mathrm{C}$ steam curing.

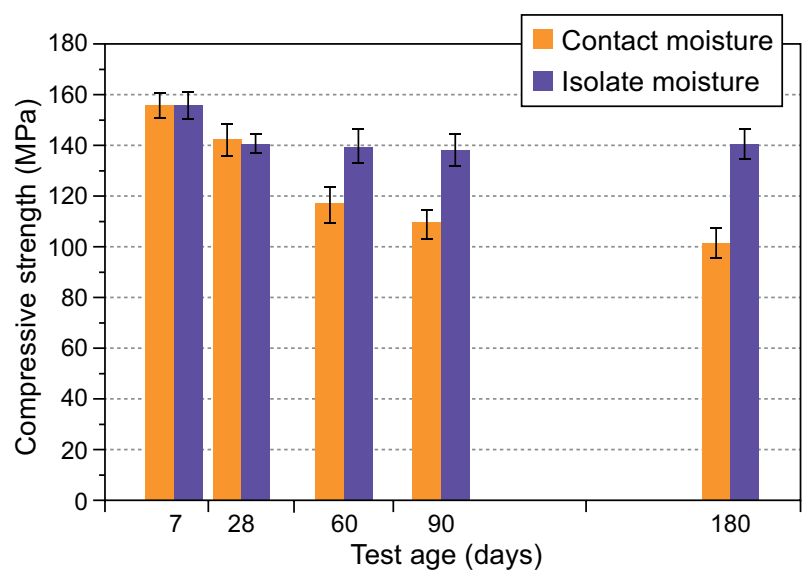

a) Compressive strength
The mechanical properties of the samples under $250{ }^{\circ} \mathrm{C}$ heat curing are shown in Figure 5. A significant decrease was observed in the long-term age compressive strength, especially when the samples were in contact

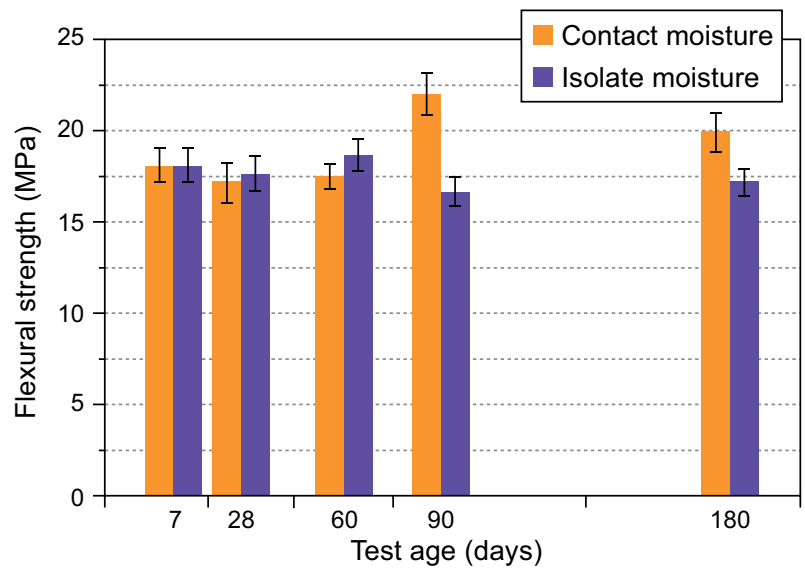

b) Flexural strength

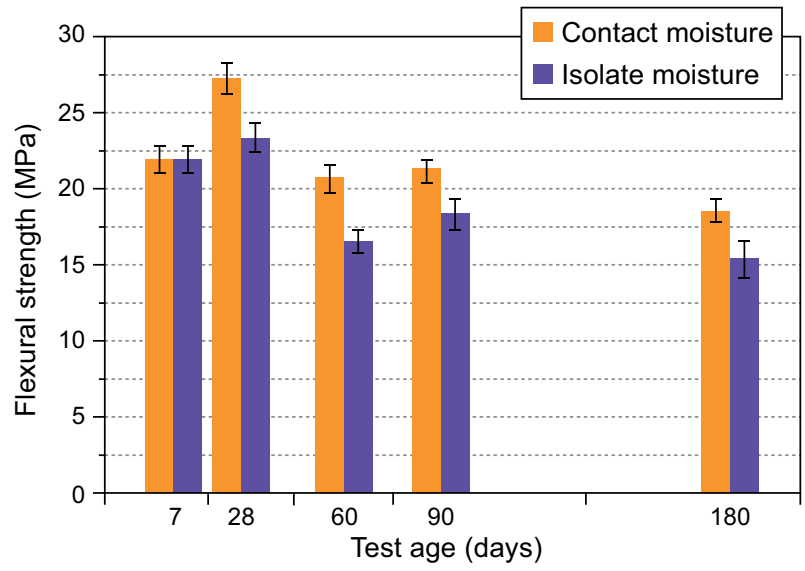

b) Flexural strength

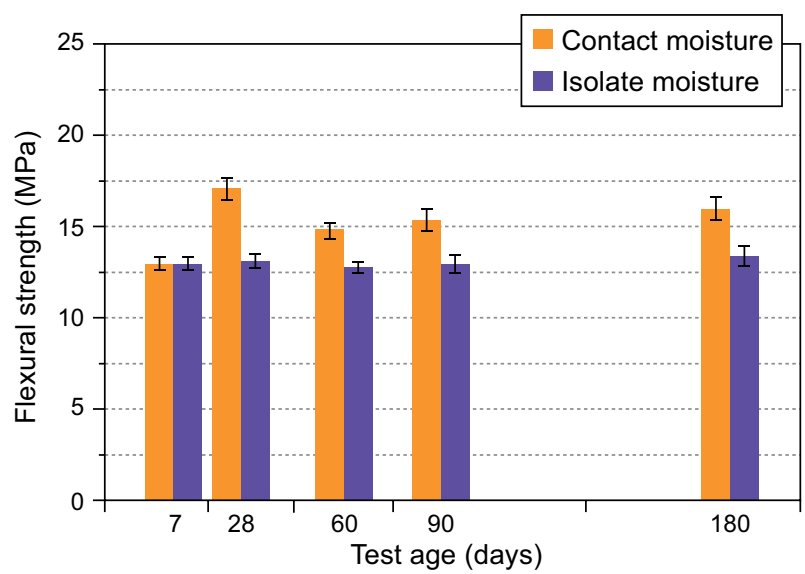

b) Flexural strength

Figure 5. Strength after the $250{ }^{\circ} \mathrm{C}$ heat curing. 
with moisture. Compared with the isolated water group, the compressive strength of the UHPC exposed to water was decreased by $34.8 \%$ and that of the isolated water group was reduced by $9.7 \%$. Moreover, the flexural strength of the UHPC specimens could still be improved by contact with moisture.

Moisture exposure has a positive effect on the UHPC strength in the long-term, and it can continuously improve the UHPC strength after both the $20^{\circ} \mathrm{C}$ standard curing and $90{ }^{\circ} \mathrm{C}$ steam curing in the long-term. Contact with moisture will significantly reduce the compressive strength of the UHPC samples in the later period, but the impact of the flexural strength is relatively low with heat curing at $250{ }^{\circ} \mathrm{C}$.

\section{Micro performance XRD analysis}

Changes in the three groups of specimens after the contact moisture and isolated moisture at 7, 60 and 180 days were tested by XRD, and the results are shown in Figure 6. The influence of the contact moisture and isolated moisture on the phase composition of the three groups of specimens is small and almost unchanged within 180 days. However, the hydration of the specimen could be significantly accelerated by high-temperature heat curing. There was no significant calcium hydroxide in the specimen under the $90{ }^{\circ} \mathrm{C}$ steam curing and $250{ }^{\circ} \mathrm{C}$ heat curing. The XRD results showed that the compressive strength shrinkage of the specimen after heat curing at $250{ }^{\circ} \mathrm{C}$, especially the more severe compressive strength shrinkage caused by contact moisture, was not obviously correlated with the phase composition inside the specimen and the hydration products did not change. However, tobermorite and xonotlite were found, which had a significant correlation with the early strength improvement in the $250{ }^{\circ} \mathrm{C}$ heat curing environment.
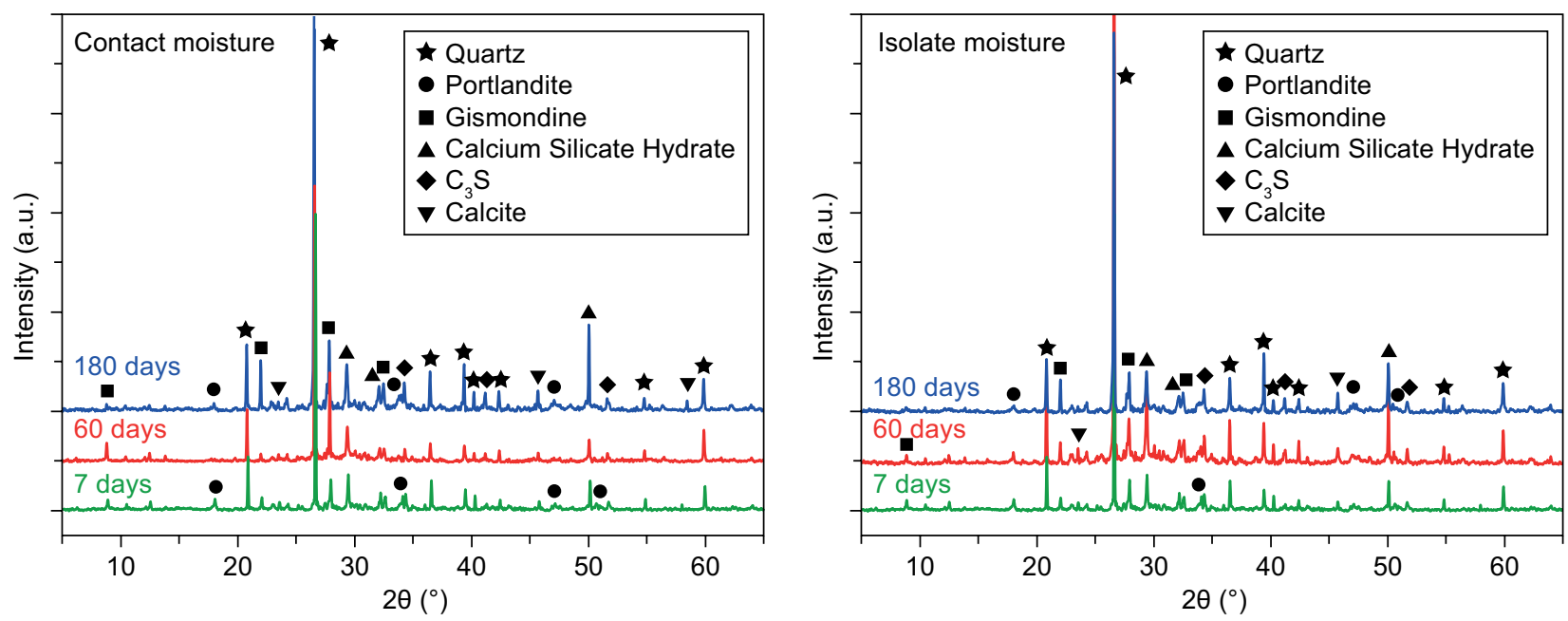

a) $20{ }^{\circ} \mathrm{C}$ standard curing
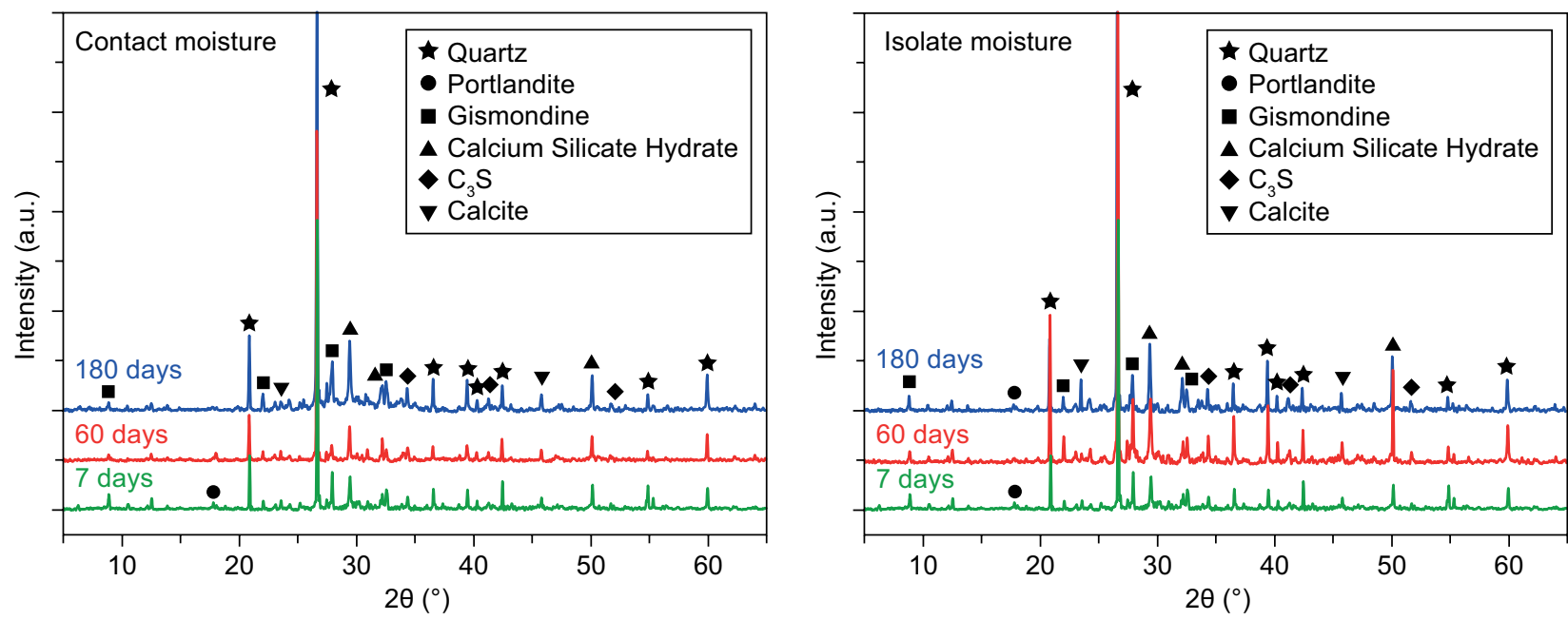

b) $90{ }^{\circ} \mathrm{C}$ steam curing

Figure 6. XRD of the specimens at the different ages. (Continue on next page) 
Wu X., Luo Y., Yang W., Gao Y., Bi Y., Xie Y.
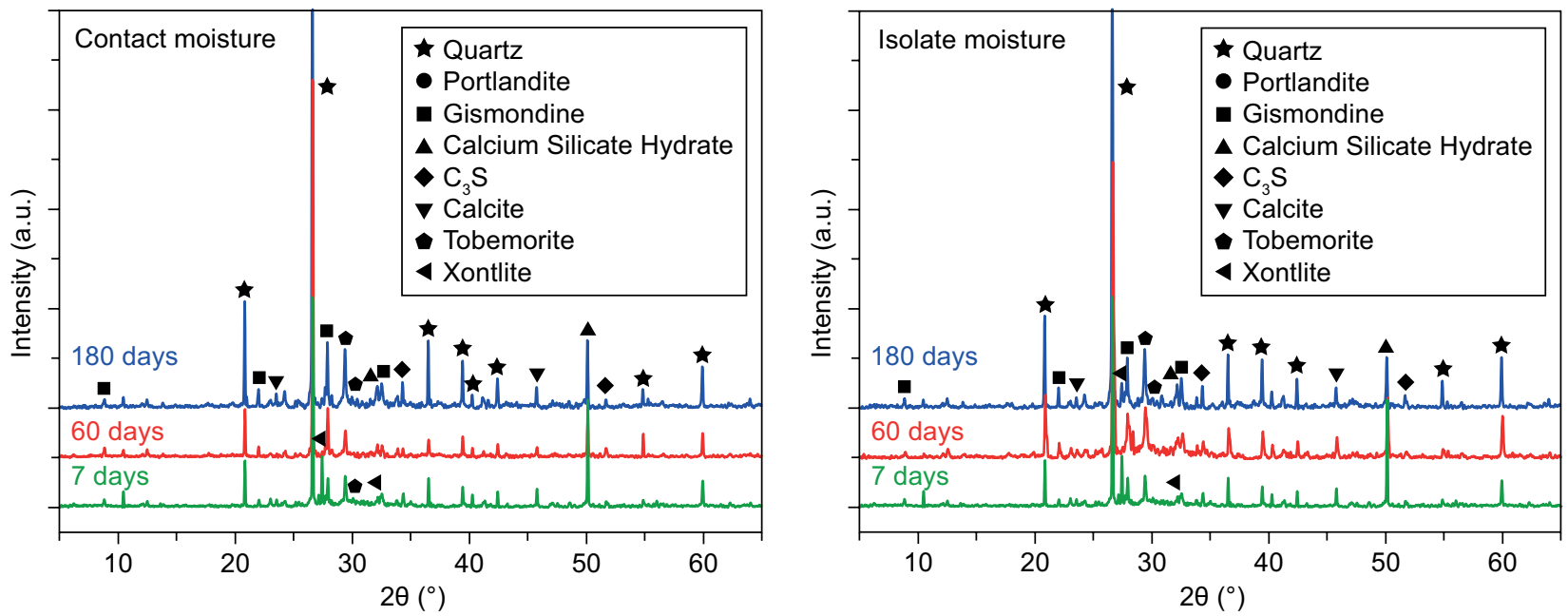

c) $250{ }^{\circ} \mathrm{C}$ heat curing

Figure 6. XRD of the specimens at the different ages.
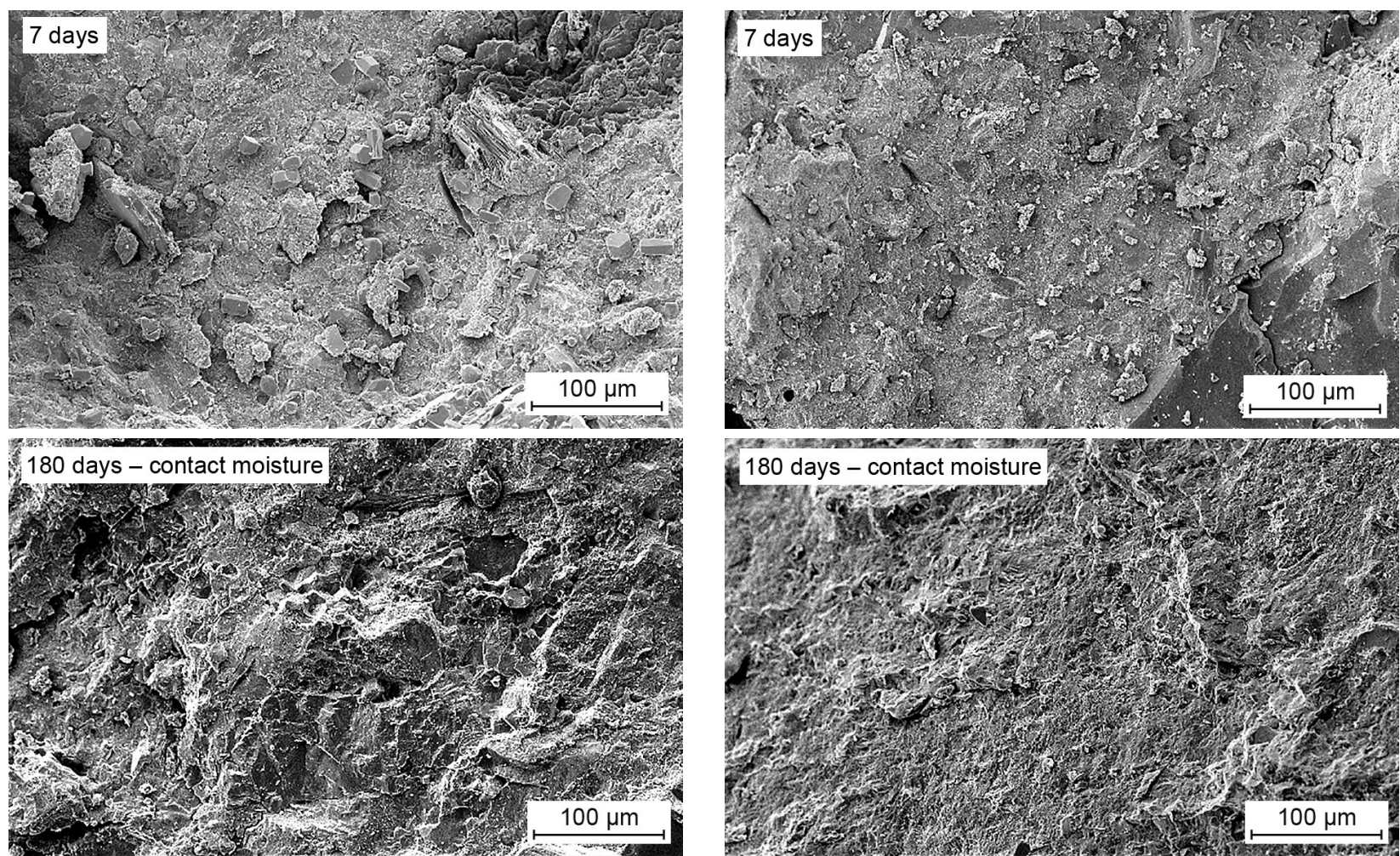

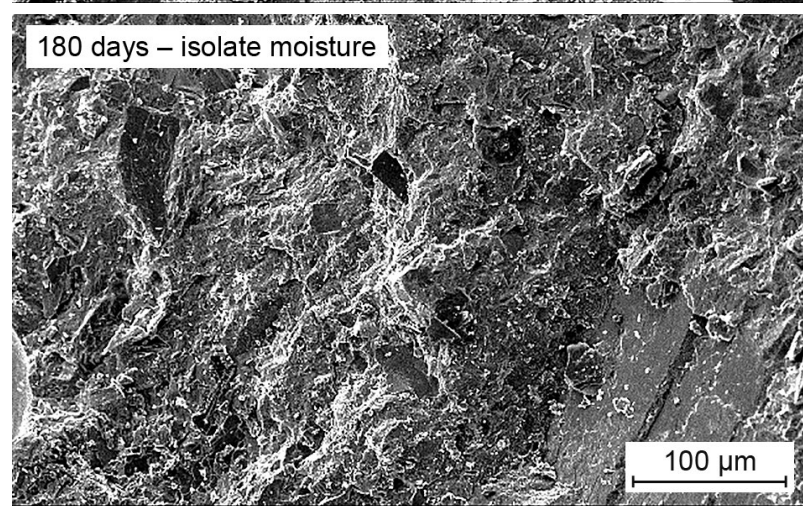

a) $20^{\circ} \mathrm{C}$ standard curing

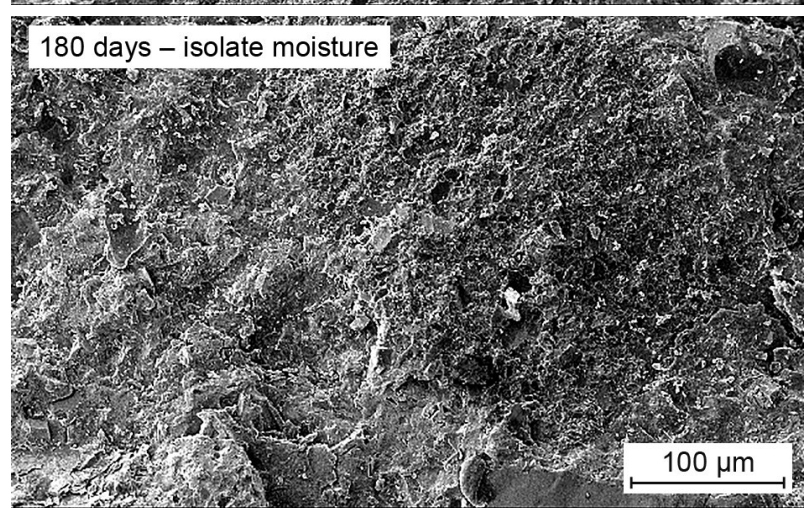

b) $90{ }^{\circ} \mathrm{C}$ steam curing

Figure 7. SEM of the specimens at the different ages. (Continue on next page) 


\section{SEM analysis}

The three groups of specimens were analysed by SEM at 7 days and 180 days after the contact moisture and isolated moisture, and the results are shown in Figure 7. No difference in the microstructure was observed between the specimens in the contact moisture and isolated moisture treatments at 180 days under the $20^{\circ} \mathrm{C}$ standard curing and $90{ }^{\circ} \mathrm{C}$ steam curing. Compared with the $20^{\circ} \mathrm{C}$ standard curing and $90{ }^{\circ} \mathrm{C}$ steam curing, obvious pores were found in the specimen at the $250^{\circ} \mathrm{C}$ heat curing. In addition, the crystal morphology of the material inside the micropores was obviously different in the contact moisture and isolated moisture environment at 180 days, with the contact moisture specimen showing flaky material and the isolated water specimen showing needle-like material. The SEM results showed that the
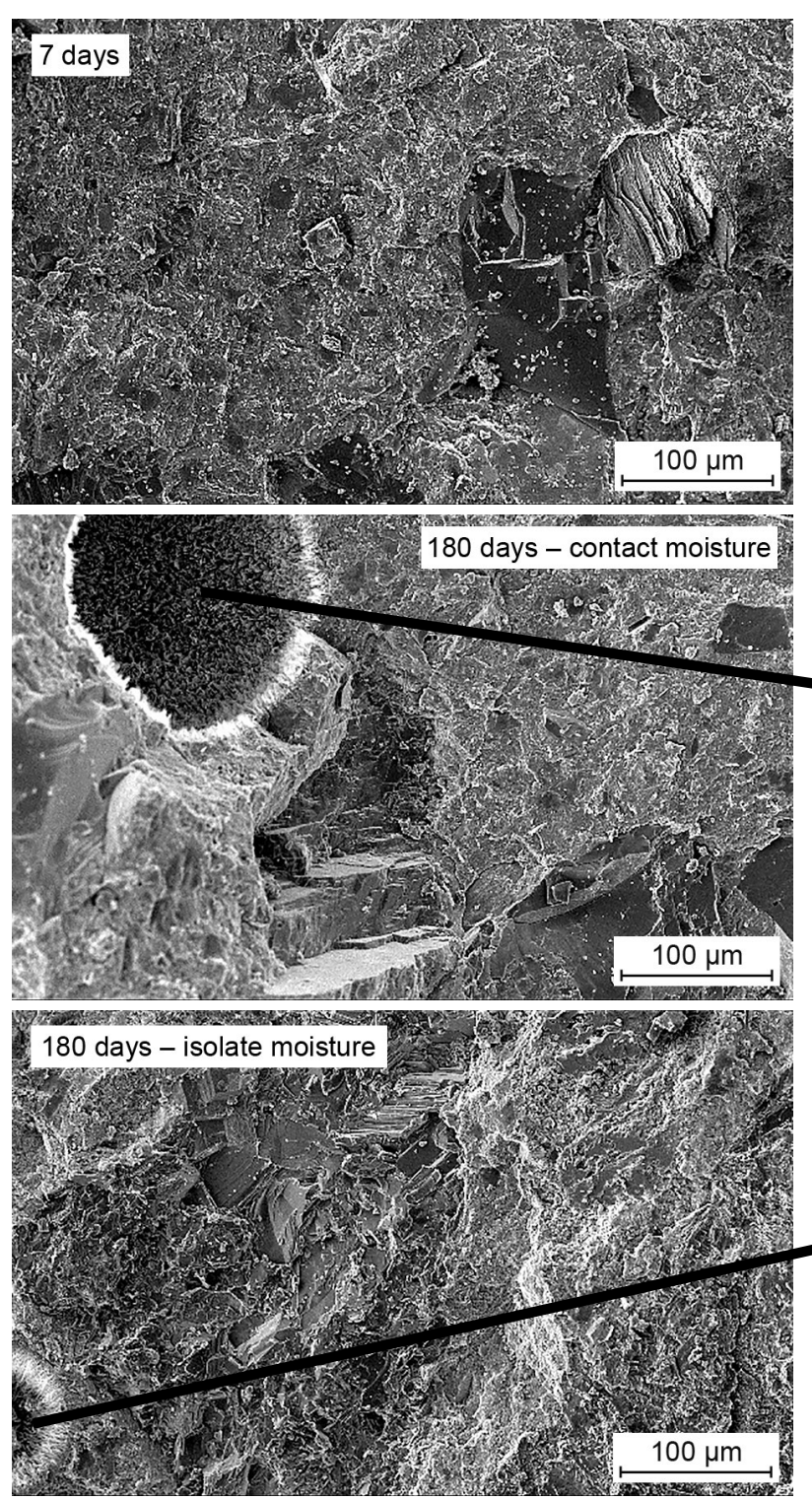

c) $250{ }^{\circ} \mathrm{C}$ heat curing obvious compressive strength shrinkage and the significant difference between the contact moisture and isolated moisture treatments were closely related to the microstructure changes of the specimens under $250{ }^{\circ} \mathrm{C}$ heat curing.

\section{MIP analysis}

To study the influence of the changes in the pore structure of the specimens after heat curing, the pore structures of three groups of specimens under the contact moisture and isolated moisture environments were tested at 7 days and 180 days, respectively. Based on the test results, the pore size distribution was calculated, and the results are shown in Table 4, Figure 8 and Figure 9. The specimens in the contact moisture environment showed a slight decrease in porosity at 180 days compared with those at 7 days, while the specimens in the isolated moisture environment showed a marked increase in porosity under the $20{ }^{\circ} \mathrm{C}$ standard curing. The results are consistent with the above compressive strength findings: the compressive strength of the contact moisture specimen was higher due to the lower porosity under the $20{ }^{\circ} \mathrm{C}$ standard curing. In addition, the compressive strength of the specimens in the contact moisture and isolated moisture environments at 180 days were both higher than those of the specimens at 7 days due to the change in pore size distribution. In particular, the number of pores with a diameter of $10 \sim 100 \mathrm{~nm}$ was
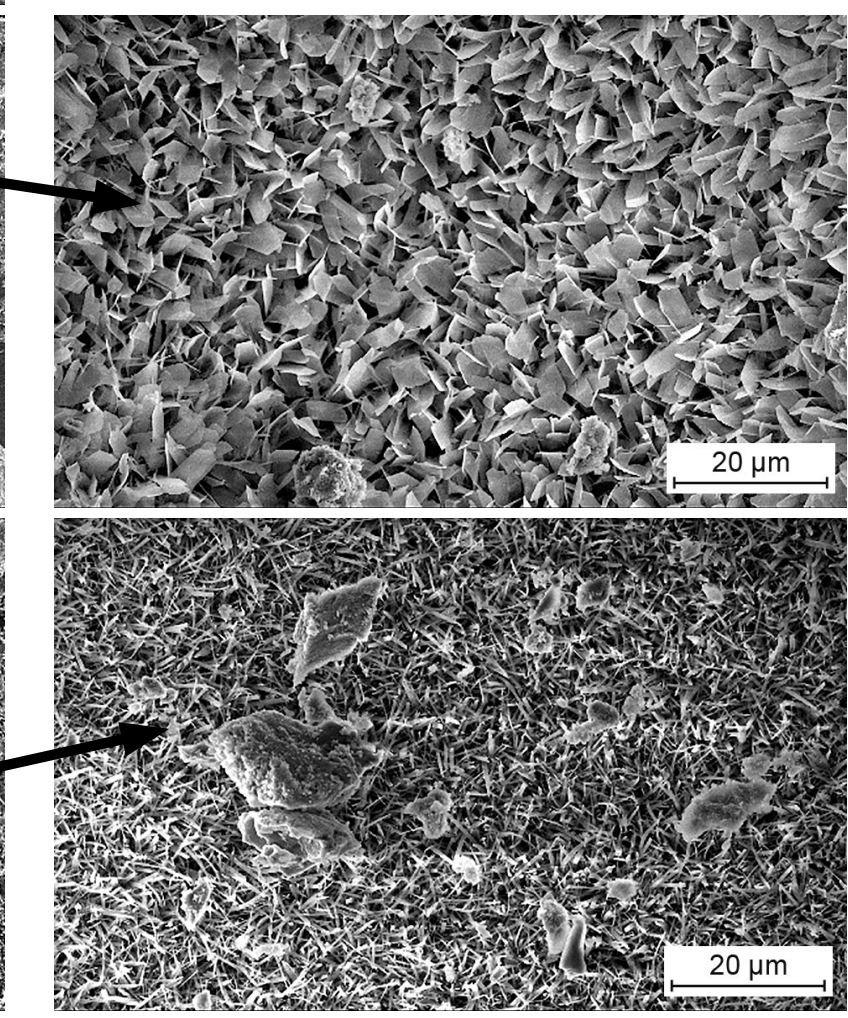

Figure 7. SEM of the specimens at the different ages.

Ceramics - Silikáty 65 (3) 305-315 (2021) 
greatly reduced, thus showing an increase in the strength. The density of the specimen was higher under the $90{ }^{\circ} \mathrm{C}$ steam curing than under the $20^{\circ} \mathrm{C}$ standard curing due to the lower porosity. Similar patterns were observed with the porosity and compressive strength of the contact moisture specimens being lower and higher than that of the isolated moisture specimens, respectively. In addition, the number of pores with a diameter of $10 \sim 100 \mathrm{~nm}$ in the $90{ }^{\circ} \mathrm{C}$ steam curing specimen was lower than that in the $20^{\circ} \mathrm{C}$ standard curing specimen.

The porosity of the $250{ }^{\circ} \mathrm{C}$ heat curing specimens was significantly higher than that of the $90{ }^{\circ} \mathrm{C}$ steam curing specimens and slightly lower than that of the $20^{\circ} \mathrm{C}$ standard curing specimens, and the number of pores with a diameter of $10 \sim 100 \mathrm{~nm}$ was significantly higher than that of the other groups at 7 days. The significant increase in the compressive strength of the specimens under the $250{ }^{\circ} \mathrm{C}$ heat curing at 7 days was due to the generation of tobermorite and xonotlite [24]. The porosity of the specimens in the contact moisture environment increased greatly while the that of the specimens in the isolated moisture environment only increased slightly at 180 days. The compressive strength of the contact moisture specimens showed serious shrinkage, and the reduction range of the isolated moisture specimens was relatively low. The MIP results showed that the pore characteristics had a greater impact on the UHPC compressive strength than the porosity and the number of pores with a diameter of $10 \sim 100 \mathrm{~nm}$.

The most important characteristic of the UHPC material is that it contains a large number of unhydrated cement particles. Water can enter and participate in the hydration reactions when cracks occur in the UHPC. The hydration of cement will lead to an increase in the solid phase volume and fill the pores and cracks, thus enabling the UHPC to self-heal. However, this property will also cause the opposite problem when the UHPC is undamaged. The change in the solid phase volume caused by the hydration after water enters the UHPC, which is already very dense, will produce cracks inside the UHPC, thus leading to a reduction in the strength. Similar patterns are observed for specimens under the $20{ }^{\circ} \mathrm{C}$ standard curing and $90{ }^{\circ} \mathrm{C}$ steam curing. The specimens were continuously hydrated in the contact

Table 4. Porosity and pore size distribution of the samples.

\begin{tabular}{|c|c|c|c|c|c|c|}
\hline \multirow[t]{2}{*}{ Samples } & \multirow{2}{*}{$\begin{array}{l}\text { Total intrusion } \\
\text { volume }\left(\mathrm{ml} \cdot \mathrm{g}^{-1}\right)\end{array}$} & \multirow{2}{*}{$\begin{array}{c}\text { Porosity } \\
(\%)\end{array}$} & \multirow{2}{*}{$\begin{array}{l}\text { Average pore } \\
\text { diameter }(\mathrm{nm})\end{array}$} & \multicolumn{3}{|c|}{ Pore size distribution $(\%)$} \\
\hline & & & & $<10 \mathrm{~nm}$ & $10 \sim 100 \mathrm{~nm}$ & $>100 \mathrm{~nm}$ \\
\hline $20^{\circ} \mathrm{C}$ standard curing -7 days & 0.0350 & 7.9762 & 20.23 & 17.49 & 53.71 & 28.80 \\
\hline $20^{\circ} \mathrm{C}$ contact moisture -180 days & 0.0389 & 7.9223 & 22.44 & 26.25 & 20.85 & 52.90 \\
\hline $20^{\circ} \mathrm{C}$ isolate moisture -180 days & 0.0418 & 9.5070 & 30.17 & 14.69 & 32.28 & 53.03 \\
\hline $90^{\circ} \mathrm{C}$ steam curing -7 days & 0.0166 & 3.7597 & 18.76 & 31.25 & 14.52 & 54.24 \\
\hline $90^{\circ} \mathrm{C}$ contact moisture -180 days & 0.0160 & 3.5633 & 17.96 & 32.82 & 14.26 & 52.92 \\
\hline $90^{\circ} \mathrm{C}$ isolate moisture -180 days & 0.0204 & 4.6254 & 23.14 & 25.16 & 15.22 & 59.62 \\
\hline $250^{\circ} \mathrm{C}$ heat curing -7 days & 0.0279 & 6.3615 & 22.65 & 14.35 & 63.72 & 21.93 \\
\hline $250^{\circ} \mathrm{C}$ contact moisture -180 days & 0.0492 & 11.1236 & 23.30 & 12.34 & 65.90 & 21.76 \\
\hline $250{ }^{\circ} \mathrm{C}$ isolate moisture -180 days & 0.0362 & 8.3532 & 19.27 & 19.09 & 61.37 & 19.54 \\
\hline
\end{tabular}
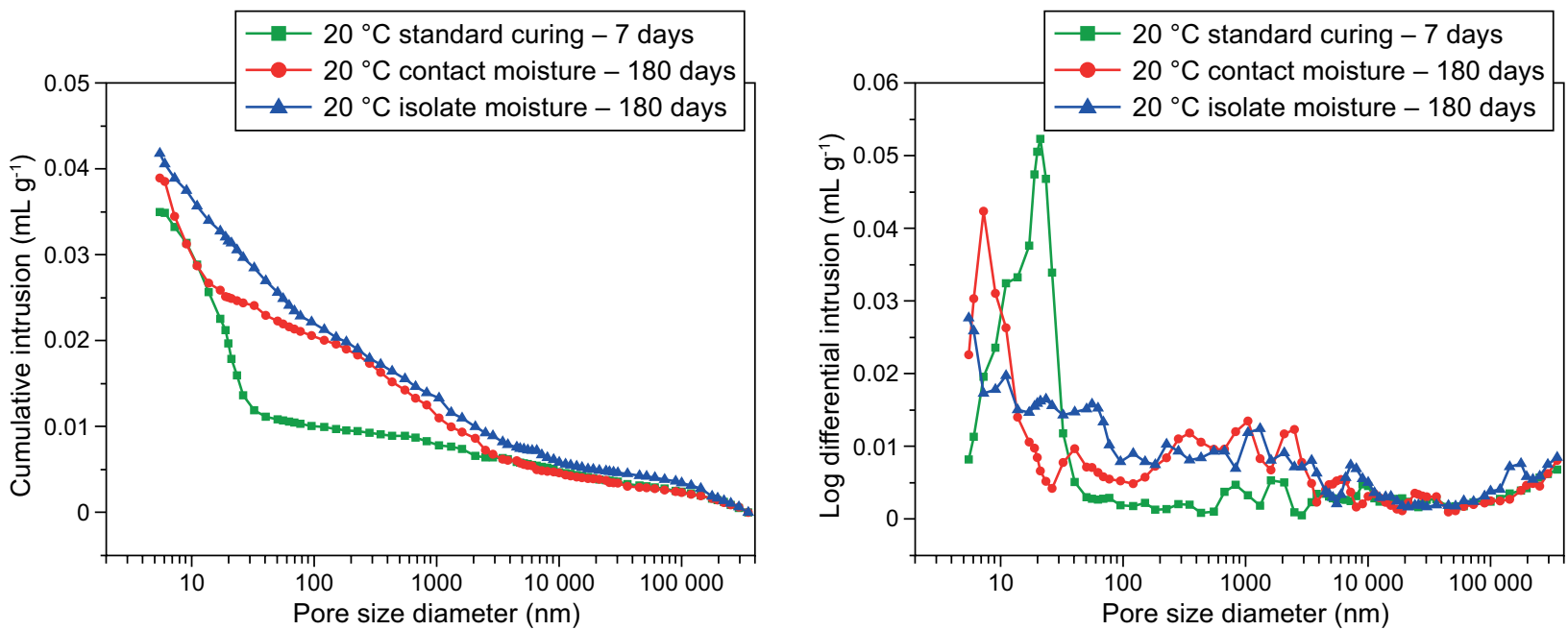

a) $20^{\circ} \mathrm{C}$ standard curing

Figure 8. MIP of the specimens at the different ages. (Continue on next page) 

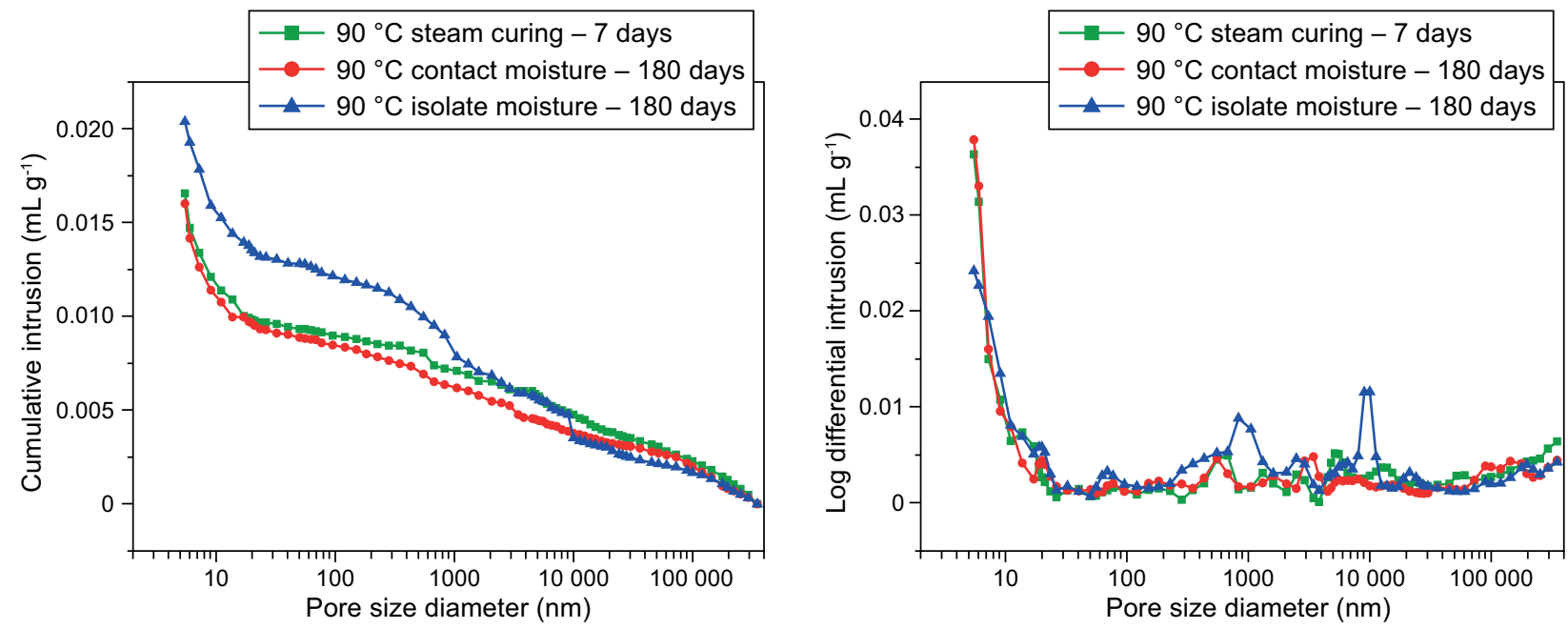

b) $90{ }^{\circ} \mathrm{C}$ steam curing
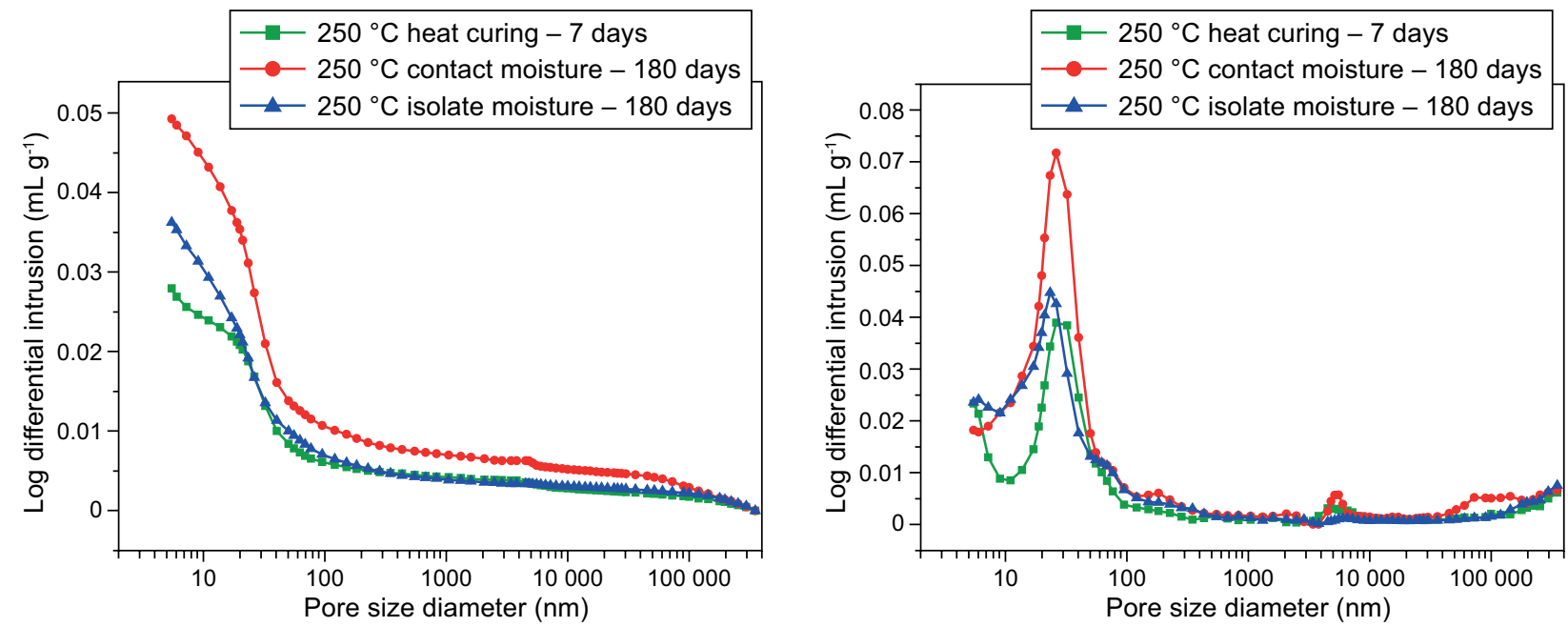

c) $250{ }^{\circ} \mathrm{C}$ heat curing

Figure 8. MIP of the specimens at the different ages.

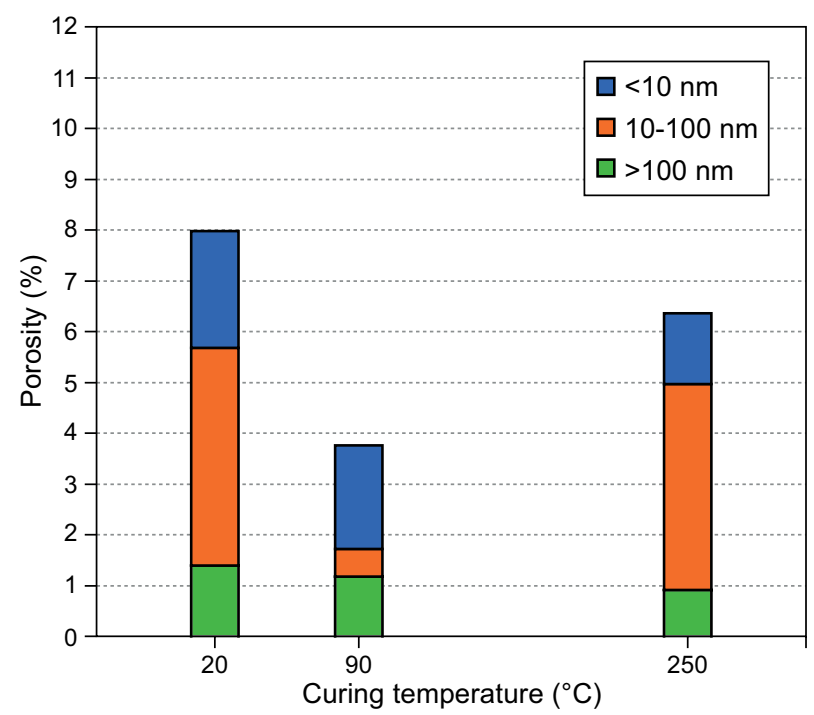

a) 7 days

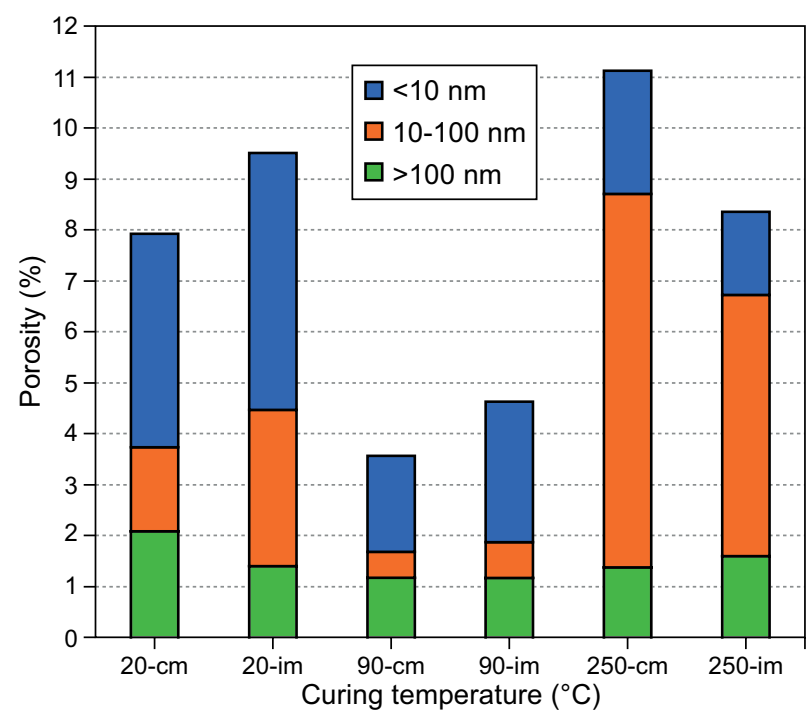

b) 180 days

Figure 9. Pore diameter distribution of the samples (cm: contact moisture; im: isolated moisture). 
Wu X., Luo Y., Yang W., Gao Y., Bi Y., Xie Y.

moisture environment within 180 days, and the porosity and the number of pores with a diameter of $10 \sim 100 \mathrm{~nm}$ both decreased. Thus, the hydration products generated by the hydration reaction when water entered the specimens were mainly filled in $10 \sim 100 \mathrm{~nm}$ pores and could significantly increase the strength of the UHPC. The later hydration of the specimens was based on the residual moisture inside the specimens in the isolated moisture environment, and the resulting limited hydration product only filled the pores with a diameter less than $10 \mathrm{~nm}$. Table 4 shows that the pores below $10 \mathrm{~nm}$ are significantly reduced and the filling of these pores has a low contribution to the UHPC strength. The cement gel solids gradually lose some of the chemically bound water at $105{ }^{\circ} \mathrm{C}$; hence, Table 4 also shows that the $10 \sim 100 \mathrm{~nm}$ pore content of the $250{ }^{\circ} \mathrm{C}$ heat cured specimens increases significantly, indicating that the loss of chemically bonded water leads to an increase in the content of $10 \sim 100 \mathrm{~nm}$ pores. The $250{ }^{\circ} \mathrm{C}$ heat cured specimens' contact moisture led to an increase in the $10 \sim 100 \mathrm{~nm}$ pores and porosity, which led to the shrinkage of the compressive strength.

\section{CONCLUSIONS}

In this paper, the effects of the moisture susceptibility of UHPC after heat curing were studied through mechanical property testing and microstructure analysis. The results are as follows.

- Compared with the isolated moisture environment, the contact moisture environment can slightly improve the strength of UHPC after 7 days of curing under $20^{\circ} \mathrm{C}$ standard curing and $90^{\circ} \mathrm{C}$ steam curing. Contact moisture can cause severe strength shrinkage, while isolated moisture had a low effect after 7 days of curing. Moreover, contact moisture can cause water stabilisation problems under $250{ }^{\circ} \mathrm{C}$ dry heat curing.

- Contact moisture and isolated moisture have small effects on the phase composition of UHPC, and they mainly affect the pore structure under the different test environments. Contact moisture can reduce the porosity of the specimens, while isolated moisture can increase the porosity of the specimens under the $20^{\circ} \mathrm{C}$ standard curing and $90{ }^{\circ} \mathrm{C}$ steam curing. Contact moisture significantly increased the porosity of the specimens, while isolated moisture slightly increased the porosity of the specimens under the $250{ }^{\circ} \mathrm{C}$ heat curing. The main influences on the strength of the UHPC specimen were the porosity inside the specimens and the content of pores with a diameter of $10 \sim 100 \mathrm{~nm}$. The lower the porosity and the lower the number of pores with a diameter of $10 \sim 100 \mathrm{~nm}$, the higher the strength of the UHPC specimen.

- A significant improvement of the compressive strength under the $250{ }^{\circ} \mathrm{C}$ curing was not achieved by reducing the porosity of the specimens, but by producing higher strength tobermorite and xonotlite. Steam curing at $90{ }^{\circ} \mathrm{C}$ can improve the strength of the specimens by reducing the porosity and improving the internal compactness of the specimens, and strength shrinkage will not occur in the later period.

\section{Acknowledgements}

The authors want to acknowledge the financial support of the National Natural Science Foundation of China (NSFC, 52002041), the China West Construction Group Co., Ltd., the Science and Technology Research and Development Foundation (ZJXJ-2019-13) and China west construction academy of building materials funding (ZJY-2021-30C).

\section{REFERENCES}

1. de Larrard F., Sedran T. (1994): Optimization of ultrahigh-performance concrete by the use of a packing model. Cement and concrete research, 24(6), 997-1009. doi: 10. 1016/0008-8846(94)90022-1

2. Tuan N. V., Ye G., Van Breugel K., Fraaij A. L., Dai Bui D. (2011): The study of using rice husk ash to produce ultra high performance concrete. Construction and Building Materials, 25(4), 2030-2035. doi: 10.1016/j.conbuildmat. 2010.11.046

3. Tuan N. V., Hanh P. H., Thanh L. T., Soutsos M. N., Goodier C. I. (2010). Ultra high performance concrete using waste materials for high-rise buildings. In: CIGOS-Conférence Franco-Vietnamienne, Loughborough University, pp.1-9.

4. Powers T. C., Brownyard T. L. (1946): Studies of the physical properties of hardened Portland cement paste. ACI Journal Proceedings. ACI, 43(9), 101-132.

5. Loukili A., Richard P., Lamirault J. (1998). A study on delayed deformations of an ultra high strength cementitious material. ACI Special Publication, pp.179.

6. Vandamme M., Ulm F. J., Fonollosa P. (2010): Nanogranular packing of $\mathrm{C}-\mathrm{S}-\mathrm{H}$ at substochiometric conditions. Cement and Concrete Research, 40(1), 14-26. doi: 10.1016/j.cemconres.2009.09.017

7. Hillemeier B., Schroder M. (1995): Poor durability of high performance concrete with water cement ratio $<0.3 / /$ Durability of high performance concrete. In: Proc. RILEM workshop Cachan France, pp 70-75.

8. Pushpalal G. K. D., Kobayashi T., Hasegawa M. (1997): High alumina cement-phenol resin composite: Water resistivity and effect of post hydration of unreacted cement on durability. Cementand ConcreteResearch, 27(9), 1393-1405. doi: 10.1016/S0008-8846(97)00130-0

9. Shen P., Lu L., He Y., Wang F., Hu S. (2019): The effect of curing regimes on the mechanical properties, nano-mechanical properties and microstructure of ultra-high performance concrete. Cement and Concrete Research, 118, 1-13. doi: 10.1016/j.cemconres.2019.01.004

10. Hiremath P. N., Yaragal S. C. (2017): Effect of different curing regimes and durations on early strength development of reactive powder concrete. Construction and Building Materials, 154, 72-87. doi: 10.1016/j.conbuildmat. 2017.07.181 
11. Yazıcı H., Yardımcı M. Y., Aydın S., Karabulut A. Ş. (2009): Mechanical properties of reactive powder concrete containing mineral admixtures under different curing regimes. Construction and Building Materials, 23(3), 1223-1231. doi: 10.1016/j.conbuildmat.2008.08.003

12. Hiremath P., Yaragal S. C. (2017): Investigation on mechanical properties of reactive powder concrete under different curing regimes. Materials Today: Proceedings, 4(9), 9758-9762. doi: 10.1016/j.matpr.2017.06.262

13. Helmi M., Hall M. R., Stevens L. A., Rigby S. P. (2016): Effects of high-pressure/temperature curing on reactive powder concrete microstructure formation. Construction and building materials, 105, 554-562. doi: 10.1016/j.conbuildmat.2015.12.147

14. Zdeb T. (2017): An analysis of the steam curing and autoclaving process parameters for reactive powder concretes. Construction and Building Materials, 131, 758-766. doi: 10.1016/j.conbuildmat.2016.11.026

15. Chen T., Gao X., Ren M. (2018): Effects of autoclave curing and fly ash on mechanical properties of ultra-high performance concrete. Construction and Building Materials, 158, 864-872. doi: 10.1016/j.conbuildmat.2017.10.074

16. Tam C. M., Wing V., Yan T. (2013): Microstructure behavior of reactive powder concrete under different heating regimes. Magazine of Concrete Research, 64(3), 259-267. doi: 10.1680/macr.2012.64.3.259

17. Peng G. F., Niu X. J., Shang Y. J., Zhang D. P., Chen X. W., Ding H. (2018): Combined curing as a novel approach to improve resistance of ultra-high performance concrete to explosive spalling under high temperature and its mechanical properties. Cement and Concrete Research, 109, 147-158. doi: 10.1016/j.cemconres.2018.04.011

18. Liu S., Sun W., ZhangY., Li G. (2002): Studies on application and mechanical properties of Ultra-High Performance Concrete. Industrial Construction, 6, 1-3.

29. Ge X., Liu J., Wang Y., et al. (2016): Effect of rehydration of unhydrated cement on ultra high performance concrete. Journal of Civil, Architectural \& Environmental Engineering, 38(01), 40-44.

20. Yang W, Huang Z., Tan L., et al. (2003): Effect of thermal curing on the strength of high performance concrete. Journal of Hunan University (Natural Sciences), S1, 150-152.

21. Ahmad S., Rasul M., Adekunle S. K., Al-Dulaijan S. U., Maslehuddin M., Ali S. I. (2019): Mechanical properties of steel fiber-reinforced UHPC mixtures exposed to elevated temperature: Effects of exposure duration and fiber content. Composites Part B: Engineering, 168, 291-301. doi: 10. 1016/j.compositesb.2018.12.083

22. Zhengyu H.F.H (2000): Study on Effect of Curing Schedule on the Strength of RPC. Concrete, 22, 31-34.

23. Wu Y., He Y., Yang Y., Li Z. (2003): The influence of curing systems on RPC strength. Journal of Fuzhou University, 5, 594-597.

24. Mostofinejad D., Nikoo M. R., Hosseini S. A. (2016): Determination of optimized mix design and curing conditions of reactive powder concrete (RPC). Construction and Building Materials, 123, 754-767. doi: 10.1016/j.conbuildmat.2016. 07.082 